\title{
PERAN LINGKUNGAN SOSIAL, PENGETAHUAN GIZI DAN PENGALAMAN DALAM PENGAMBILAN KEPUTUSAN IBU NIFAS UNTUK MELAKUKAN MUTIH DI KECAMATAN GEBOG, KABUPATEN KUDUS
}

\author{
Linda Apriliani, Hartanti Sandi Wijayanti* \\ Program Studi Ilmu Gizi Fakultas Kedokteran Universitas Diponegoro \\ Jl.Dr.Sutomo No.18, Semarang, Telp (024) 8453708, Email : gizifk@ undip.ac.id
}

\begin{abstract}
ABSTACT
Background: Mutih was one of the food taboos practiced in Gebog, Kudus that might cause nutritional problems such as anemia. Food behaviour was usually influenced by the beliefs related to level of knowledge, the evaluation of the behavior outcome or experience, social environment's view on subject behaviour and decision making control related to the subject's position in their social environment.

Objective: The aim of the study was to explore the role of social environment, nutrition knowledge and experience in the decision to practice Mutih among postpartum women.

Method: The study was a descriptive research by using qualitative method. Informants were recruited by using purposive sampling. Informants consisted of 7 pospartum women practicing Mutih, two postpartum women's mother, a postpartum women not practicing Mutih and an elder. Data was collected by using in depth interview and was proccessed by using inductive method.

Result: Family and neighbors were social environment that influenced postpartum mothers to practice Mutih, while health workers did not support the postpartum women to practice Mutih. Postpartum women had lack nutrition knowledge about the food sources and its benefits, which affect them to practice Mutih. The effect of Mutih experienced by postpartum women affected them to practice Mutih. Decision to practice Mutih was mostly made by postpartum women. They practiced Mutih because worried about uterine wounds healing.

Conclution: : Decision to practice Mutih among postpartum women was influenced by their experience, lack nutrition knowledge and the role of social environment, expecially from postpartum women's mother.
\end{abstract}

Keyword: food taboo, decision making, social environment, nutrition knowledge, experience

\section{ABSTRAK}

Latar Belakang: Mutih merupakan salah satu pantangan makanan di Kec.Gebog, Kab. Kudus yang dapat menimbulkan masalah gizi seperti anemia. Perilaku makan biasanya dipengaruhi oleh kepercayaan terhadap perilaku yang berkaitan dengan tingkat pengetahuan, evaluasi terhadap hasil perilaku atau pengalaman, pandangan lingkungan sosial terhadap perilaku subjek, dan kontrol terhadap pengambilan keputusan yang berkaitan dengan kedudukan subjek dalam lingkungan sosial.

Tujuan: Mengeksplorasi peran lingkungan sosial, pengetahuan gizi dan pengalaman dalam pengambilan keputusan ibu nifas untuk melakukan Mutih.

Metode: Penelitian ini merupakan penelitian deskriptif dengan metode kualitatif. Informan terdiri dari 7 ibu nifas Mutih, 2 orang tua ibu nifas, seorang ibu nifas tidak Mutih dan seorang tetua desa. Pemilihan informan penelitian dengan purposive sampling. Pengumpulan data menggunakan metode wawancara mendalam dan pengolahan data menggunakan metode induksi.

Hasil: Lingkungan sosial yang memiliki peran dalam mempengaruhi ibu nifas untuk melakukan Mutih adalah orang tua, suami dan tetangga, sedangkan tenaga kesehatan tidak mendukung ibu nifas untuk melakukan Mutih. Pengetahuan gizi ibu nifas yang kurang tentang sumber pangan serta manfaatnya mempengaruhi ibu nifas melakukan Mutih. Dampak yang dirasakan oleh ibu nifas dari pengalaman yang dialaminya mempengaruhi ibu nifas untuk melakukan Mutih. Pengambilan keputusan lebih banyak dilakukan oleh ibu nifas sendiri. Alasan ibu melakukan Mutih karena merasa khawatir luka uterus tidak lekas sembuh.

Simpulan: Keputusan ibu nifas untuk melakukan Mutih dipengaruhi oleh pengalaman, pengetahuan gizi yang kurang, serta peran lingkungan sosial terutama orang tua.

Kata Kunci: Mutih, pengambilan keputusan, lingkungan sosial, pengetahuan gizi, pengalaman

\section{PENDAHULUAN}

Pantang makan merupakan suatu perilaku individu untuk tidak mengkonsumsi makanan tertentu karena terdapat larangan yang bersifat budaya yang diperoleh secara turun-temurun. ${ }^{1}$ Jenis makanan yang seringkali dilarang dikonsumsi oleh ibu hamil dan ibu nifas adalah makanan yang asam dan pedas, daging, seafood, serta beberapa jenis sayuran dan buah. ${ }^{2,3,4}$ Di Kecamatan Gebog, Kabupaten Kudus terdapat pantangan makanan yang disebut Mutih. Jenis makanan yang dilarang dikonsumsi saat melakukan Mutih adalah daging,

${ }^{*}$ Penulis Penanggungjawab 
seafood, sayuran, buah, unggas, ikan dan telur. Ibu yang tidak mengkonsumsi daging, seafood, sayuran dan buah dapat mengalami kekurangan asupan protein, zat besi, seng, asam folat, vitamin A dan vitamin B12 yang dapat menyebabkan ibu hamil dan ibu nifas mengalami anemia. ${ }^{2}$ Data Riskesdas 2013 menunjukan angka prevalensi anemia pada ibu hamil sebesar $37,1 \%$, sedangkan data SKRT 2005 menyebutkan prevalensi anemia pada ibu nifas sebesar $45,1 \% .^{5,6}$

Ada beberapa faktor yang mempengaruhi ibu nifas untuk mengambil keputusan, termasuk dalam hal melakukan pantang makanan. Berdasarkan Theory of Planned Behaviour, intensi yang merupakan keputusan untuk melakukan perilaku tertentu ditentukan oleh tiga faktor yaitu sikap terhadap perilaku, norma subjektif, dan kontrol terhadap pengambilan keputusan. Sikap terhadap perilaku didasarkan pada kepercayaan yang dipengaruhi tingkat pengetahuan dan evaluasi terhadap hasil perilaku atau pengalaman. Norma subjektif ditentukan oleh pandangan dan harapan yang berasal dari lingkungan sosial serta motivasi untuk memenuhi harapan tersebut. Kontrol terhadap pengambilan keputusan ditentukan oleh kedudukan dalam lingkungan sosial yang akan menentukan power atau kekuatan yang dimiliki subjek..$^{7,8,9}$

Pengetahuan merupakan faktor dominan yang sangat penting dalam terbentuknya suatu tindakan. Perilaku yang didasari oleh pengetahuan akan lebih langgeng daripada perilaku yang tidak didasari pengetahuan. ${ }^{7}$ Pengetahuan erat kaitannya dengan dasar pengambilan keputusan berdasarkan fakta dan rasional. Seseorang dengan tingkat pengetahuan yang tinggi akan cenderung berfikir secara rasional dalam mengambil sebuah keputusan. ${ }^{9}$

Pengalaman atau evaluasi terhadap hasil perilaku dapat menentukan keputusan di masa mendatang. Seseorang akan mengharapkan dampak tertentu dari suatu perilaku. Apabila perilaku memberikan dampak postitif atau sesuai dengan yang diharapkan maka orang akan cenderung mengulangi perilaku tersebut, sedangkan bila perilaku memberikan dampak negatif maka orang tidak akan mengulangi perilaku sebelumnya. ${ }^{8}$

Lingkungan sosial berperan dalam memberikan pandangan dan harapan terhadap perilaku subjek. Lingkungan sosial meliputi orang yang tinggal dekat atau memiliki hubungan dekat dengan pengambil keputusan seperti orang tua, pasangan, tetangga, teman, dan tenaga kesehatan. ${ }^{9}$ Orang-orang tersebut memiliki peran dalam norma subjektif yang akan mempengaruhi pengambilan keputusan. Hal ini juga berkaitan dengan posisi atau kedudukan subjek dalam lingkungan sosial yang akan menetukan power atau kekuasaan untuk melakukan suatu perilaku. ${ }^{8}$ Berdasarkan konsep peranan pria/wanita secara tradisional, pembuatan keputusan-keputusan keluarga dilakukan oleh suami, namun keluarga besar terutama ibu atau ibu mertua juga akan mempengaruhi pengambilan keputusan khususnya tentang pemilihan makanan yang boleh dikonsumsi ibu nifas karena ibu atau ibu mertua dianggap lebih tahu tentang apa saja yang harus dilakukan saat masa nifas. Di Nepal, ibu mertua memiliki power dan kontrol atas anak dan menantu, termasuk dalam hal perawatan kehamilan hingga melahirkan. ${ }^{10}$

Faktor-faktor yang menyebabkan ibu nifas melakukan Mutih perlu digali sebagai dasar penentuan intervensi yang tepat untuk menyelesaikan masalah perilaku yang kurang menguntungkan bagi kesehatan ibu. Untuk itu, peneliti ingin mengetahui bagaimana peran lingkungan sosial, pengetahuan dan pengalaman dalam mempengaruhi pengambilan keputusan pada ibu nifas yang melakukan Mutih.

\section{METODE PENELITIAN}

Penelitian dilaksanakan di Kecamatan Gebog, Kabupaten Kudus pada bulan Juli-Agustus 2015. Penelitian ini merupakan penelitian deskriptif yang dilakukan dengan menggunakan metode kualitatif. Metode kualitatif dipilih untuk menggali faktor yang berperan dalam pengambilan keputusan ibu nifas untuk melakukan puasa Mutih.

Pengambilan informan dilakukan menggunakan metode purposive sampling. Triangulasi data dilakukan kepada ibu dan ibu mertua informan, ibu nifas yang tidak Mutih, serta tetua yang dianggap paling tahu tentang tradisi Mutih. Kriteria informan untuk triangulasi data adalah dekat atau tinggal bersama informan (untuk ibu kandung mertua dan ibu nifas yang tidak Mutih), mampu berkomunikasi dengan baik dan bersedia diwawancarai dengan mengisi informed consent.

Pemilihan informan dimulai dengan pencarian data ibu nifas di Puskesmas Gondosari dan beberapa bidan desa. Total informan penelitian adalah 11 informan yang terdiri dari 7 ibu nifas yang Mutih, dua orang ibu (orang tua ibu nifas), seorang ibu nifas yang tidak Mutih, dan seorang tetua desa. Pengumpulan data dilakukan menggunakan metode wawancara mendalam (in depth interview). ${ }^{11}$ Data yang dikumpulkan antara lain data identitas informan meliputi nama, alamat, umur, pendidikan, pekerjaan, jumlah anak, dan data wawancara mendalam meliputi praktik Mutih, peran lingkungan sosial, dan pengetahuan gizi. 
Instrumen yang digunakan untuk pengambilan data adalah peneliti sendiri sebagai pengumpul data (interviewer), asisten peneliti sebagai note taker untuk mencatat poin penting yang perlu digali dan situasi saat wawancara berlangsung, pedoman wawancara, dan alat perekam suara. Data yang diperoleh selanjutnya diolah dengan metode induksi. ${ }^{12}$ Analisis data dilakukan melalui beberapa tahapan, yang meliputi koding data, reduksi data, kategorisasi, penyajian data, serta pengambilan kesimpulan dan verifikasi. Pada tahap koding dilakukan seleksi dan penyederhanaan data yang sesuai dengan topik penelitian. Reduksi data dilakukan pada data yang tidak berhubungan dengan pengambilan keputusan ibu nifas untuk melakukan Mutih. Kategorisasi dilakukan dengan memilah data sesuai dengan kesamaan yang selanjutnya diberi label. Data yang telah diberi label disusun dalam bentuk matrik, kemudian diambil kesimpulan sehingga diperoleh gambaran secara sistematis mengenai peran lingkungan, pengetahuan, dan pengalaman dalam pengambilan keputusan ibu nifas untuk melakukan Mutih. $^{11,13}$

\section{HASIL PENELITIAN \\ Karakteristik Informan}

Informan terdiri dari 7 ibu nifas yang melakukan Mutih.

Tabel 1. Karakteristik Informan

\begin{tabular}{cccccc}
\hline Informan & $\begin{array}{c}\text { Umur } \\
\text { (tahun) }\end{array}$ & Pendidikan & $\begin{array}{c}\text { Jumlah } \\
\text { anak }\end{array}$ & $\begin{array}{c}\text { Keluarga yang } \\
\text { tinggal bersama }\end{array}$ & Pekerjaan \\
\hline I1 & 24 & SMP & 1 & Ibu, suami & Mengurus rumah tangga \\
I2 & 36 & SMP & 3 & Ibu, suami, anak & Penjahit \\
I3 & 32 & SD & 3 & Suami, anak & Mengurus rumah tangga \\
I4 & 28 & SD & 2 & Ibu, Suami, anak & Buruh \\
I5 & 28 & SD & 2 & Suami, anak & Karyawan Pabrik \\
I6 & 34 & SD & 2 & Suami, anak & Mengurus rumah tangga \\
I7 & 28 & SMP & 2 & Suami, anak & Mengurus rumah tangga \\
\hline
\end{tabular}

Tabel 1 menunjukkan umur informan berada pada rentang antara 24-36 tahun. Tingkat pendidikan informan tergolong pendidikan rendah sampai sedang, yaitu SD dan SMP. Sebagian besar informan memiliki dua hingga tiga anak sehingga memiliki pengalaman Mutih sebelumnya, kecuali satu orang yang memiliki satu anak. Informan tinggal bersama keluarga inti kecuali tiga informan yang juga tinggal bersama ibu. Sebagian besar informan mengurus rumah tangga, sedangkan tiga informan lain bekerja sebagai penjahit, buruh, dan karyawan pabrik.

\section{Praktik Mutih}

Mutih adalah istilah lokal di daerah penelitian untuk menyebut pantangan makanan pada ibu nifas. Jenis makanan yang dikonsumsi saat melakukan Mutih menurut informan adalah nasi, tahu, tempe dan beberapa jenis sayuran. Sayuran yang dikonsumsi sebagian besar informan adalah kacang panjang dan labu siam, sedangkan sayuran lain seperti kangkung, pepaya muda, wortel, sawi, buncis, daun katuk dan kentang hanya dikonsumsi oleh beberapa informan.

Mutih yang dilakukan saat ini berbeda dengan praktik Mutih pada zaman dahulu. Seorang tetua mengatakan bahwa Mutih pada awalnya hanya mengkonsumsi nasi dan garam yang disebut uyah songo, yaitu garam yang disangrai. Seiring dengan perkembangan zaman, makanan yang dapat dikonsumsi bertambah menjadi nasi, tahu dan tempe karena ibu merasa tidak kuat jika hanya mengkonsumsi nasi dan garam saja. Cara pengolahan tahu dan tempe tidak boleh digoreng, tetapi dikukus karena minyak dianggap bersifat licin sehingga dapat membahayakan rahim ibu. Praktik Mutih yang dilakukan saat ini pun kembali mengalami perubahan karena ada beberapa sayuran yang boleh dikonsumsi oleh ibu selain tahu dan tempe, meskipun kriteria sayuran yang boleh dikonsumsi tidak terlalu jelas. Berdasarkan keterangan dari informan, perubahan ini terjadi karena adanya peran dari bidan dan dokter yang menganjurkan untuk makan sayuran demi kesehatan ibu dan anak.

"...Mutih zaman dahulu (makannya) garam, uyah songo. Garamnya disangrai. Kalau saya sama tahu tempe. Masaknya dibotok, dibungkus pakai daun begitu. Katanya kalau digoreng, rahim itu mila mili, nggak mau diam gitu. Bisa geser kesana kemari...” (tetua, 76 tahun)

Golongan makanan yang tidak dikonsumsi saat melakukan Mutih adalah lauk hewani, sayur dan buah. Ikan, ayam dan telur tidak dikonsumsi karena dipercaya dapat menyebabkan bayi berbau amis. Seorang informan menyatakan ayam dan telur juga dapat menyebabkan luka kandungan (rahim) sulit sembuh. Selain lauk hewani, beberapa jenis sayuran yang tidak dikonsumsi diantaranya nangka 
muda, daun lembayung, kol, cabai, bayam, dan kecambah. Mengkonsumsi nangka muda, lembayung, dan kol dapat menyebabkan rahim terasa gatal, darah keluar kembali, dan luka rahim sulit sembuh. Salah seorang informan menyatakan nangka muda bersifat tajam seperti pisau, sehingga menyebabkan darah keluar kembali. Cabai tidak dikonsumsi karena dapat menyebabkan bayi diare, sedangkan bayam menyebabkan tubuh terasa lemas. Informan yang tidak mengkonsumsi kecambah menganggap kecambah dapat menyebabkan cepat hamil kembali. Seorang informan juga menambahkan kecap kedalam daftar makanan yang dipantang karena dapat menyebabkan darah keluar kembali.

“...(yang nggak boleh) ya ayam, telur, ikan laut. Kalau lembayung ya nggak boleh, kol juga, kecambah, nangka muda nggak boleh. (telur, ikan, ayam) kan membuat bayi berbau amis. (nangka muda dan lembayung) menyebabkan gatal di dalam perut, bisa mengeluarkan darah lagi. (kol) sama saja, bisa menyebabkan darah keluar. Kalau makan pedas nanti bayinya diare. Kalau kecambah bikin cepat punya anak lagi..." (I.3, 32 tahun)

Berdasarkan keterangan dari beberapa informan, Mutih dilakukan kurang lebih selama 40 hari. Lama Mutih bervariasi karena bergantung pada kekuatan dari masing-masing orang. Pernyataan tersebut juga didukung oleh keterangan dari tetua yang menyatakan bahwa Mutih dilakukan selama 40 hari, akan tetapi ada pula orang yang kuat melakukan Mutih hingga setahun.

Pada saat melakukan Mutih, porsi makanan yang dikonsumsi lebih sedikit dari porsi biasanya saat tidak sedang menyusui. Jumlah nasi yang biasa dikonsumsi sebanyak 1-2 centong, tahu dan tempe rata-rata 2 potong setiap kali makan, sedangkan sayuran hanya sekitar 2-3 sendok makan. Meskipun sebagian besar informan tidak mengetahui penyebab porsi makan harus lebih sedikit dari biasanya, namun ada seorang informan yang menyatakan akibat dari mengkonsumsi makanan dalam porsi besar adalah menyebabkan usus menjadi melebar.

\section{Pengalaman dalam Pengambilan Keputusan Melakukan Mutih}

Sebagian besar informan telah memiliki lebih dari satu anak. Hal ini menunjukkan bahwa informan telah memiliki pengalaman Mutih sebelumnya. Dampak yang dirasakan informan selama melakukan Mutih bervariasi, seperti merasa cepat kurus, sedikit lemas, bosan dan agak mual. Namun demikian, ada pula informan yang mengaku merasa biasa saja melakukan Mutih.
Seorang informan menyatakan bahwa Mutih menyebabkan cepat kurus karena makanan yang dikonsumsi jumlahnya sedikit, berbeda dengan orang yang tidak Mutih. Anggapan ini didukung oleh keterangan dari tetua yang menyatakan Mutih membuat tubuh tidak gemuk dan kembali langsing.

“...(Mutih) maksudnya di badan itu pertama terasa ringan, kedua gemuknya bukan gemuk yang bergelambir, cepat singset..." (tetua, 76 tahun)

Selain merasa cepat kurus, dampak lain yang timbul akibat melakukan Mutih adalah informan merasa bosan karena makanan yang dikonsumsi kurang bervariasi, yaitu tahu dan tempe selama 40 hari. Seorang informan menyatakan meskipun merasa bosan tetapi tetap tidak berani makan makanan yang dipantang walaupun sedikit karena takut akan membahayakan kesehatan.

Manfaat Mutih yang dirasakan ibu nifas adalah luka cepat sembuh dan bayi tidak berbau amis. Seorang informan menyatakan pernah mengkonsumsi sedikit kecap saat Mutih dan menyebabkan darah keluar kembali. Hal ini menyebabkan informan takut dan tidak berani lagi untuk mengkonsumsi makanan yang dipantang. Sebaliknya, seorang ibu nifas yang tidak Mutih pernah mengkonsumsi sayur nangka muda dan menyatakan bahwa perut tidak terasa gatal dan tidak mengeluarkan darah kembali. Hal ini menandakan bahwa efek yang ditimbulkan akibat mengkonsumsi makanan yang dipantang tidak terbukti.

Selain pengalaman yang dialami sendiri, informan juga mengamati pengalaman yang dialami orang lain. Salah seorang informan yang belum pernah melakukan Mutih sebelumnya menyatakan bahwa pernah menemui bayi yang berbau amis karena ibunya tidak melakukan Mutih. Bau bayi yang amis ini berasal dari ASI ibu yang amis akibat mengkonsumsi segala jenis makanan termasuk makanan yang seharusnya dipantang. Selain menyebabkan bayi berbau amis, air kencing bayi juga berbau pesing. Informan menyatakan bahwa bayinya tidak amis dan air kencingnya tidak pesing karena dia melakukan Mutih.

“...pernah tahu orang yang tidak Mutih, makannya sembarang gitu lho mbak, sembarang dimakan, anaknya amis, air kencingnya juga pesing sekali. (kalau bayiku) ya nggak amis, air kencingnya juga tidak pesing..." (I.1, 24 tahun)

\section{Peran Keluarga dalam Pengambilan Keputusan Melakukan Mutih}

Keluarga yang memiliki peran dalam pengambilan keputusan ibu nifas adalah ibu dan suami. Peran ibu bervariasi mulai dari menyerahkan 
keputusan kepada ibu nifas, memberikan informasi tentang Mutih, hingga menyuruh untuk melakukan Mutih. Ibu yang berperan dalam memberikan informasi menyampaikan tentang makanan apa yang harus dikonsumsi dan yang tidak pada saat masa nifas. Informasi yang diberikan ibu seringkali tidak disertai dengan alasan mengapa harus melakukan Mutih. Seorang informan merasa ingin tahu alasan kenapa tidak boleh mengkonsumsi makanan yang dipantang namun tidak berani untuk bertanya kepada ibunya.

Salah seorang informan yang melakukan Mutih atas perintah ibunya menyatakan ibu tidak memberikan kesempatan kepada informan untuk memilih melakukan Mutih atau tidak. Hal ini sesuai dengan hasil triangulasi kepada ibu informan yang meyatakan bahwa dirinya langsung menyuruh anaknya Mutih tanpa meminta pendapat dari anaknya.

“...ya langsung saya suruh Mutih. enggak, enggak saya tanya (mau Mutih atau tidak), sudah tahu kok, sudah nurut sama saya..." (ibu I.1, 52 tahun)

Peran suami dalam pengambilan keputusan ibu nifas adalah sebagai orang yang mengikuti keputusan ibu nifas, kecuali salah satu suami informan yang marah jika istrinya tidak melakukan Mutih. Meskipun keputusan terakhir diserahkan kepada istri, namun seorang suami memiliki peran dalam mengingatkan dampak yang timbul jika tidak Mutih.

“...(suami) nggak memarahi. Ya terserah kamu kalau memang mau anaknya sehat ya nurut, kalau enggak ya enggak, gitu..." (I.7, 28 tahun)

Beberapa suami informan mengikuti keputusan istrinya namun menyerahkan seluruh dampak yang dapat timbul kepada istrinya. Peran lain dari suami informan adalah memberikan dukungan kepada ibu nifas untuk melakukan Mutih. Bentuk dukungan yang diberikan suami adalah dengan membelikan tahu dan tempe setiap hari untuk dikonsumsi istrinya yang melakukan Mutih.

\section{Peran Tenaga Kesehatan dalam Pengambilan Keputusan Melakukan Mutih}

Berdasarkan hasil wawancara dengan informan, diperoleh temuan mengenai peran bidan dan dokter dalam pengambilan keputusan untuk melakukan Mutih. Sebagian besar bidan dan dokter telah menyarankan kepada ibu nifas untuk tidak Mutih, kecuali satu bidan yang tidak memberikan saran apapun kepada ibu nifas. Saran biasanya diberikan setelah proses melahirkan.

Bidan biasanya menyiapkan makanan bagi ibu nifas selama perawatan di klinik berupa berupa ayam, lele, telur, tahu, tempe, dan sayur bening.
Beberapa informan menyatakan bahwa makanan yang dikonsumsi pasca melahirkan di klinik bidan hanya tahu dan tempe meskipun disiapkan ayam, telur dan lele. Sebaliknya, salah seorang informan menyatakan bahwa semua makanan boleh dikonsumsi karena di tempat praktek bidan diberikan obat, sehingga tidak berbahaya jika makan ayam, telur, atau ikan lele. Namun demikian, ketika tiba di rumah harus menghindari makanan tersebut karena dapat membahayakan kesehatan ibu. Ibu nifas harus bisa menjaga diri sendiri karena di rumah tidak ada obat dari bidan.

Bidan biasanya memberikan saran kepada ibu nifas untuk tidak melakukan Mutih. Beberapa bidan menyampaikan bahwa sayuran harus dikonsumsi karena ibu sedang menyusui sehingga memerlukan vitamin untuk bayinya, juga agar bayi menjadi sehat. Namun demikian, ada bidan yang hanya menyarankan untuk tidak Mutih tanpa menjelaskan alasannya. Selain bidan, dokter juga berperan dalam memberikan saran kepada ibu nifas. Seorang dokter menyarankan untuk makan telur dan ayam agar luka jahitan cepat sembuh, sedangkan dokter lainnya menyarankan untuk tidak Mutih karena ibu membutuhkan vitamin untuk ASI-nya. Meskipun demikian, ibu nifas tidak mengikuti saran bidan dan dokter karena tetap merasa takut jika luka kandungan tidak lekas sembuh.

\section{Peran Tetangga dalam Pengambilan Keputusan Melakukan Mutih}

Setelah melahirkan, ibu nifas seringkali mendapat kunjungan dari tetangga sekitar. Pada saat mengunjungi ibu nifas, beberapa tetangga mengingatkan untuk melakukan Mutih dengan menyampaikan tentang apa saja yang tidak boleh dikonsumsi ketika menjalani Mutih. Meskipun demikian, ada pula tetangga yang bersikap biasa saja terhadap ibu nifas. Hal ini dapat dikarenakan Mutih sudah menjadi tradisi di wilayah tersebut sehingga setiap orang dianggap sudah tahu bahwa setelah melahirkan seharusnya melakukan Mutih. Salah seorang informan menyatakan bahwa ada tetangga yang memarahi jika ada orang yang tidak Mutih. Orang tersebut akan diberitahu akibat jika tidak melakukan Mutih.

\section{Pengetahuan Gizi}

Pengetahuan gizi informan sebagian besar diperoleh dari bidan atau dokter. Beberapa informan telah mengetahui bahwa makan beragam dibutuhkan agar ASI mengandung vitamin untuk bayinya. Sebagian besar informan menyatakan bahwa sayuran merupakan makanan yang dapat mempercepat penyembuhan. Selain itu, sayuran dapat menjadi sumber makanan yang sehat bagi bayi. Seorang informan mengetahui bahwa sayur 
dan buah adalah sumber vitamin, sedangan seorang informan lain menyatakan bahwa sumber vitamin adalah obat dan sayur.

Pengetahuan informan tentang sumber pangan serta manfaatnya masih kurang. Beberapa informan menyatakan bahwa sayuran yang mengandung vitamin hanya brokoli, wortel, dan sawi. Pengetahuan gizi lain yang dimiliki ibu nifas adalah tentang makanan yang dapat memperlancar ASI yaitu pepaya muda dan daun katuk. Walaupun sudah mengetahui bahwa sayur dapat mempercepat penyembuhan luka dan baik untuk bayinya, namun informan tetap melakukan Mutih.

“... soalnya kan menyusui biar vitaminnya banyak kayaknya. Kan minumnya air susu dari $i b u$, kalau ibunya makan yang mengandung protein dan vitamin kan biar masuk ke bayinya, biar bayinya dapat vitamin banyak. (manfaat vitamin) kayaknya biar bayinya sehat. (manfaat protein) ya sama saja mbak. (sumber vitamin) ya sayur itu, buah. Ya wortel, sawi, brokoli, pisang. (makanan yang bikin cepat sembuh) saya tidak tahu mbak, ( kalau makanan untuk memperlancar ASI) katuk itu mbak, pepaya (muda)... ya (tetap) Mutih, takut (nggak sembuh) mbak aku. Nanti kan boleh makan sembarang kalau sudah 40 hari, nggak papa (anak nggak dapat vitamin banyak)..." (I.1, 24 tahun)

\section{Keputusan Melakukan Mutih}

Sebagian besar informan melakukan Mutih atas keinginan sendiri. Alasan ibu nifas melakukan Mutih adalah merasa khawatir jika luka uterus tidak cepat sembuh dan tidak ingin bayinya berbau amis. Hal ini juga sesuai dengan manfaat yang dirasakan oleh beberapa informan, yaitu luka cepat sembuh dan bayi tidak berbau amis. Ketakutan dan kepercayaan terhadap bahaya yang timbul akibat mengkonsumsi makanan pantangan dapat menyebabkan ibu memutuskan untuk melakukan Mutih.

“...ya karena keinginan sendiri mbak. sebenarnya ya tidak ingin (Mutih) tapi takut. Takut lukanya itu, yang di dalam (perut)..." (I.3, 36 tahun)

“...(manfaat Mutih) di luka cepat sembuh mbak, nang bayi yo gak amis...” (I.1, 24 tahun)

Kepercayaan ibu nifas terhadap manfaat Mutih diperkuat dengan pengalaman yang dialami baik oleh diri sendiri maupun orang lain. Pengalaman seorang informan yang mengkonsumsi kecap sehingga darah keluar kembali meyebabkan informan tersebut semakin yakin bahwa kepercayaannya terhadap bahaya jika tidak melakukan Mutih memang benar. Selain itu, pengalaman menemui bayi berbau amis karena ibunya tidak Mutih juga menyebabkan ibu percaya akibat jika tidak Mutih.

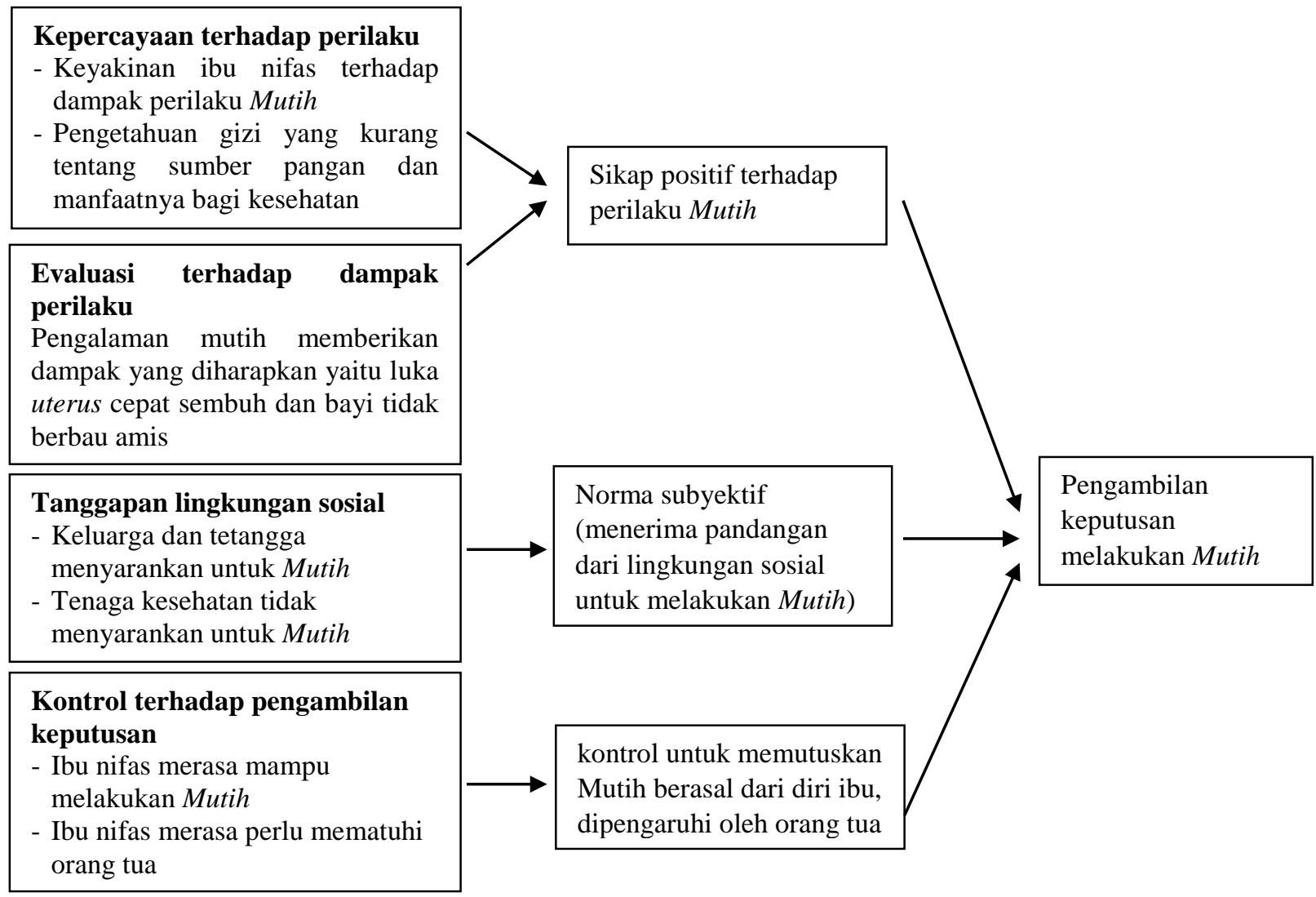

Bagan 1. Pengambilan keputusan ibu nifas untuk melakukan Mutih 
Berdasarkan hasil wawancara, pengetahuan gizi informan terbatas hanya pada manfaat sayuran bagi kesehatan ibu dan bayi. Meskipun sebagian besar informan mengetahui tentang pentingnya mengkonsumsi sayuran namun dalam prakteknya informan tetap melakukan Mutih. Hal ini terjadi karena informan tetap merasa takut luka di rahim sulit sembuh, bahkan terdapat dua orang informan yang menyatakan bahwa kesembuhan lukanya lebih penting dibandingkan dengan bayi yang dapat kekurangan vitamin akibat melakukan Mutih.

Meskipun sebagian besar ibu nifas melakukan mutih atas keinginan sendiri, namun keputusan melakukan Mutih juga dapat berasal dari ibu. Hal ini menunjukkan bahwa ibu sebagai anggota keluarga turut berperan dalam mengambil keputusan. Dua informan menyatakan bahwa mereka melakukan Mutih atas perintah ibunya.

Di lain pihak, ibu nifas yang tidak Mutih mengakui dirinya tidak mempercayai bahaya yang dapat timbul akibat tidak melakukan Mutih. Ibu tersebut menyatakan Mutih hanya terdapat di desanya saja, sedangkan di tempat lain tidak ada orang yang melakukan Mutih. Menurutnya, ibu dan bayi tetap sehat meskipun tidak melakukan Mutih. Selain itu, ibu nifas yang tidak Mutih pernah memiliki pengalaman mengkonsumsi nangka muda yang tidak menimbulkan dampak berupa darah keluar kembali. Pengalaman yang dialami ibu nifas ini menyebabkan ibu tidak percaya terhadap manfaat Mutih.

Mengacu pada Theory of Planned Behaviour, pengambilan keputusan ibu nifas untuk melakukan mutih ditunjukkan dalam bagan sebagai berikut.

\section{PEMBAHASAN}

Mutih merupakan salah satu budaya pantangan makanan bagi ibu nifas di Kecamatan Gebog yang dilakukan untuk menjaga kesehatan ibu dan bayinya. Pengambilan keputusan untuk memilih suatu makanan terkadang tidak didasari oleh pertimbangan yang rasional. Hal ini sulit diubah karena dalam budaya sudah mengakar kepercayaan terhadap suatu makanan tertentu yang dipantang. ${ }^{1}$ Ibu nifas percaya bahwa mengkonsumsi makanan seperti ikan, ayam dan telur dapat menyebabkan bayi berbau amis dan luka kandungan sulit sembuh. Makanan dalam konteks sosial budaya memang memiliki makna yang lebih luas dibandingkan sekedar bahan konsumsi manusia. Kepercayaan yang keliru terhadap hubungan antara makanan dan kesehatan menyebabkan orang tidak bisa memanfaatkan makanan yang tersedia bagi mereka. ${ }^{1}$
Ibu nifas yang melakukan Mutih memiliki kepercayaan bahwa mengkonsumsi ikan, ayam, telur, dan sayur dapat menyebabkan luka rahim sulit sembuh dan bayi berbau amis sehingga tidak mengkonsumsi makanan tersebut. Makanan yang dipantang sebenarnya memiliki kandungan gizi yang baik bagi ibu nifas dan bayinya. Ikan, ayam dan telur merupakan sumber protein hewani yang mengandung zat besi dan vitamin B12 yang dibutuhkan tubuh untuk pembentukan hemoglobin, sedangkan sayuran mengandung asam folat yang berperan dalam pembentukan sel darah merah. Asupan protein, zat besi, vitamin $\mathrm{B} 12$ dan asam folat yang kurang selama masa nifas dapat menyebabkan ibu menderita anemia. ${ }^{14,16}$

Proses penyembuhan luka uterus pada ibu nifas terjadi kurang lebih selama 6 minggu. Selama proses tersebut, uterus dan jalan lahir bayi akan mengalami perubahan hingga mencapai keadaan seperti saat sebelum hamil. ${ }^{15}$ Konsumsi makanan yang mengandung protein justru akan mempercepat penyembuhan luka karena protein berperan dalam pembentukan sel dan jaringan baru. Selain itu, konsumsi sayuran yang mengandung vitamin B kompleks dan vitamin $\mathrm{C}$ juga dapat mempercepat penyembuhan karena merupakan co-enzim dalam berbagai fungsi metabolisme yang terlibat dalam penyembuhan luka dan berperan penting dalam sintesis kolagen. ${ }^{14,16}$

Kepercayaan lain terhadap akibat mengkonsumsi makanan yang dipantang adalah menyebabkan bayi berbau amis. Kepercayaan ini bersifat subjektif karena penilaian amis dari masingmasing informan berbeda. Hal ini juga didukung hasil observasi peneliti yang menunjukkan bahwa bayi dari ibu nifas yang Mutih maupun yang tidak melakukan Mutih tidak berbau amis. Sindrom tubuh berbau amis seperti ikan atau yang dikenal dengan Fish Odor Syndrome merupakan gangguan metabolisme tubuh yang cukup langka terjadi. Fish Odor Syndrome biasanya hanya terjadi sementara pada bayi yang lahir prematur. ${ }^{17}$

Pengetahuan gizi yang dimiliki ibu nifas tidak cukup untuk membuat ibu nifas menghindari perilaku Mutih. Meskipun sebagian besar informan mengetahui bahwa sayuran dibutuhkan untuk menjaga kesehatan ibu dan bayi, namun konsumsi sayur masih sangat terbatas karena ibu tetap merasa takut luka kandungan sulit sembuh. Pengetahuan tidak cukup untuk mengubah perilaku sesorang karena dalam perubahan perilaku dipengaruhi oleh faktor lain seperti sikap, kepercayaan dan motivasi. Pengetahuan merupakan domain kognitif yang menjadi tahap awal dari perubahan perilaku sehingga perubahan perlaku tidak dapat muncul 
secara langsung. Perubahan pengetahuan harus disertai dengan perubahan sikap agar terjadi perubahan perilaku. ${ }^{7}$

Lingkungan sosial memiliki peran dalam pengambilan keputusan ibu nifas. Sebagai makhluk sosial, manusia tidak dapat hidup tanpa bantuan orang lain, manusia membutuhkan dukungan sosial dari orang-orang disekitarnya. Dukungan sosial dapat berupa info verbal atau non verbal, saran, bantuan yang nyata atau tingkah laku yang diberikan oleh orang-orang yang akrab dengan ibu nifas di dalam lingkungan sosialnya. ${ }^{18}$ Berdasarkan hasil penelitian, orang tua (ibu) berperan dalam memberikan perintah atau anjuran untuk melakukan Mutih, sedangkan suami mengikuti keputusan istri dengan menyerahkan dampak kepada istri dan ada pula yang memberikan dukungan untuk melakukan Mutih. Kedudukan ibu dalam rumah tangga berhubungan dengan kebudayaan dalam masyarakat. Dalam kebudayaan Jawa, posisi wanita dalam keluarga sangat kuat, terutama dalam pekerjaan rumah tangga yang berhubungan dengan proses reproduksi. Kekuatan atau power yang dimiliki ibu lebih besar dari anak perempuannya. ${ }^{17}$ Selain ibu, tetangga juga memiliki peran dalam memberikan saran dan informasi terkait Mutih. Hal ini menunjukkan bahwa orang-orang di sekitar ibu nifas mendukung untuk melakukan Mutih.

Lingkungan sosial tidak seluruhnya mendukung ibu nifas melakukan Mutih. Tenaga kesehatan seperti bidan dan dokter memiliki peran dalam memberikan saran kepada ibu nifas untuk tidak melakukan Mutih. Saran dari tenaga kesehatan yang belum dipatuhi oleh ibu nifas dapat diakibatkan oleh pendekatan yang belum tepat. Hal ini terjadi karena tenaga kesehatan belum mengetahui apa yang dirasakan oleh kelompok sasaran mengenai perilaku tersebut sehingga saran yang disampaikan belum sesuai dengan kebutuhan. ${ }^{7}$ Sebagian besar bidan dan dokter telah menyampaikan bahwa sayuran perlu dikonsumsi untuk kesehatan ibu dan bayinya. Informasi yang disampaikan bidan belum sesuai dengan kebutuhan ibu nifas yaitu untuk menghilangkan rasa takut terhadap luka yang sulit sembuh akibat mengkonsumsi makanan yang dipantang. Ketakutan ibu nifas terhadap luka yang sulit sembuh harus dihilangkan terlebuh dahulu agar ibu nifas bersedia untuk tidak melakukan Mutih.

Sebagian besar ibu nifas melakukan Mutih atas keinginannya sendiri karena merasa takut luka tidak sembuh dan bayi berbau amis. Pengambilan keputusan ini tidak didasarkan oleh alasan yang rasional. Hal ini dapat diakibatkan karena pengetahuan ibu nifas yang kurang terkait dengan manfaat makanan yang dipantang seperti ikan, telur, ayam, dan sayur. Kepercayaan ibu nifas terhadap manfaat melakukan Mutih didukung oleh pengalaman yang dialami ibu nifas selama melakukan Mutih. Selain itu, lingkungan sosial seperti ibu dan tenaga kesehatan juga dapat mempengaruhi keputusan ibu nifas. Ibu berperan dalam memberikan perintah dan anjuran untuk melakukan Mutih. Tenaga kesehatan yaitu bidan dan dokter telah berupaya untuk memberikan saran untuk tidak melakukan Mutih meskipun belum menunjukkan hasil yang maksimal. Peran tenaga kesehatan dapat dioptimalkan untuk merubah perilaku ibu nifas yang melakukan Mutih.

\section{SIMPULAN}

Keputusan ibu nifas untuk melakukan Mutih dipengaruhi oleh pengalaman Mutih yang memberikan dampak sesuai dengan harapan ibu nifas serta pengetahuan gizi yang kurang tentang sumber pangan dan manfaatnya. Lingkungan sosial yang paling berperan dalam mempengaruhi ibu nifas untuk melakukan Mutih adalah orang tua, sedangkan tenaga kesehatan tidak mendukung ibu nifas untuk melakukan Mutih. Pengambilan keputusan lebih banyak dilakukan oleh ibu nifas sendiri. Alasan ibu melakukan mutih karena merasa khawatir luka uterus tidak lekas sembuh.

\section{SARAN}

Petugas kesehatan terutama bidan perlu memberikan konseling kepada ibu nifas untuk mengatasi rasa khawatir terhadap luka yang sulit sembuh. Materi yang dapat disampaikan adalah penyebab luka sulit sembuh dan manfaat makanan yang dipantang bagi penyembuhan luka. Apabila rasa khawatir ibu sudah hilang, maka dapat dilakukan penyuluhan lebih lanjut mengenai gizi pada ibu nifas meliputi makanan yang seharusnya dikonsumsi dan risiko jika ibu melakukan Mutih.

\section{DAFTAR PUSTAKA}

1. Momon S. Sosiologi Untuk Kesehatan. Jakarta: Salemba Medika; 2008. p.157-164.

2. Afiayah SH. Pengaruh Tabu Makanan, Tingkat Kecukupan Gizi, Kosnusmsi Tablet Besi, dan Teh Terhadap Kadar Hemoglobin pada Ibu Hamil di Kota Pekalongan. [Thesis]. Semarang: Universitas Diponegoro; 2006.

3. Kyi KS. Beliefs and practices surrounding postpartum period among Myanmar women. Midwifery. 2003; 29:1257-1263.

4. Barbara AP. Forty days and forty nights: A biocultural perspective on postpartum practices in the Amazon. Social Science \& Medicine. 2008; 67:1094-1103. 
5. Kementrian Kesehatan RI. Riset Kesehatan Dasar: Riskesdas 2013. Jakarta: Kementrian Kesehatan RI; 2013.

6. Kementrian Kesehatan RI. Badan Survei Kesehatan Rumah Tangga: SKRT 2005. Jakarta: Kementrian Kesehatan RI; 2005.

7. Notoatmodjo S. Promosi Kesehatan dan Ilmu Perilaku. Jakarta: PT Rineka Cipta; 2007.

8. Edberg M. Buku Ajar Kesehatan Masyarakat: Teori Sosial dan Perilaku. Jakarta: Penerbit Buku Kedokteran; 2009.p.60-65.

9. Contento IR. Nutrition Education. Canada: Jones and Barlett Publisher; 2007.

10. Bibha S, Maureen AP, Edwin RT. The role of mothers-in-law in antenatal care decision-making in Nepal: a qualitative study. BMC Pregnancy and Childbirth. 2010; 10(34):1471-2393.

11. Moleong LJ. Metode Penelitian Kualitatif. Bandung: PT. Remaja Rosdakarya. 2006.p.155156.

12. Kusnanto H. Metode Kualitatif dalam Riset Kesehatan. Yogyakarta: Universitas Gajah Mada; 2001.p.1-9.

13. Sugiyono. Memahami Penelitian Kualitatif. Bandung: CV Alvabeta; 2008.

14. Anderson JJB. Minerals. In: Mahan LK, Stumps SE, editors. Krause's food, nutrition, and diet therapy. 11th ed. Philadelphia: Saunders; 2004.p.138-148.

15. Guyton AC, Hall JE. Buku Ajar Fisiologi Kedokteran [Irawati, Ramadani D, Indriyani F]. Edisi 11. Jakarta: EGC; 1997.p.1318.

16. Whitney E, Rolfes SR. Understanding Nutrition. 11th ed. USA: Thomson Wadsworth; 2008. p.195,342-442.

17. Jeffrey M, Shane C, Susan M, Mark B. A review of Trimethylaminuria: (Fish Odor Syndrome). J Clin Aesthet Dermatol. 2013 Nov; 6(11):45-48.

18. Pudjiwati S. Peranan Wanita dalam Perkembangan Masyarakat Desa. Jakarta: CV Rajawali; 1983.p.3240.

19. Sarlito WS, Eko AM, Bagus T, Istiqomah W, Rizka H, Sri FM, et al. Psikologi Sosial. Jakarta: Salemba Humanika; 2009.p.180-183. 